УДК 811.111:371

DOI: $10.24144 / 2617-3921.2020 .18 .309-320$

Леся Кушмар

кандидат філологічних наук, доиент кафедри іноземної філології та перекладу, Київський національний торговельно-економічний університет orcid.org/0000-0003-0407-6267

Київ, Україна, +380509519905

l.kushmar@knute.edu.ua

Любов Колот

старший викладач кафедри іноземної філології та перекладу, Київський національний торговельно-економічний університет orcid.org/0000-0003-4491-9169

Киї, Україна, +380635394170

l.kolot@knute.edu.ua

Ольга Дубініна

старший викладач кафедри іноземної філології та перекладу, Київський наиіональний торговельно-економічний університет orcid.org/0000-0001-5688-6806 Київ, Україна, +380630247185 o.dubinina@knute.edu.ua

\title{
Формування SOFT SKILLS на основі Business Partner (Пірсон)
}

Анотація. Стаття стосується аналізу навчального комплексу Business Partner (Пірсон), що є яскравим прикладом формування soft skills у майбутніх успішних професіоналів, адже останні дослідження ринку пращі відображають тендениію підвищеної зачікавленості працедавиів саме до таких навичок. Тому розгляд питання розвитку soft skills y студентів nid час опанування дисиипліни ІМПС надзвичайно важливе, щчо зумовлює актуальність дослідження. Для систематичного опису ілюстративного та теоретичного матеріалу стосовно досліджуваної проблематики був застосований описовий метод з прийомами контекстуального аналізу. Метод відбору прикладів дав можливість виявити та систематизувати завдання, що сприяють успішному формуванню soft skills. Єдиного перекладу терміна soft skills на разі не існує, тому найчастіше при перекладі це «м'які», людські або уніфіковані навички (компетенціï). Soft skills - сочіологічний термін, який відноситься до емоційного інтелекту людини. Це навички, вміння та характеристики, які дозволяють бути успішними у професійній діяльності. До них відносять: лідерські якості та вміння працювати у команді, вміння навчати та проводити переговори, вміння ставити та досягати поставлених иілей, управління часом, иілеспрямованість, презентаційні навички, навички 
ефективної комунікаиії, стресостійкість, креативність, творчий підхід до вирішення завдань та аналітичні здібності, тощо. Проте, сталого переліку, як $і$ класифікації soft skills, не існує. Навчальний комплекс Business Partner передбачає модель зміманого навчання $i$ включає найновішу сучасному розвитку економіки тематику й дозволяє успішно формувати наступні soft skills: комплексне багаторівневе вирішення проблем, критичне мислення, креативність в широкому сенсі, уміння управляти людьми, взаємодія 3 людьми, емоційний інтелект, формування власної думки та прийняття рішень, клієнтоорієнтованість, уміння вести переговори, когнітивна гнучкість розуму. Саме иі навички було визначено на Всесвітньому економічному форумі в Давосі як основні. Успішне формування soft skills на основі Business Partner дозволяє досягати вершин у всіх сферах професійної діяльності людини. Перспектива подальших досліджень передбачає залучення студентів до анкетування з метою виявлення глибини формування soft skills на основі Business Partner.

Ключові слова: soft skills, Business Partner, англійська мова, навички майбутнього, професіонал, іноземна мова за професійним спрямуванням.

Abstract. The article deals with the analysis of the training complex Business Partner (Pearson) to be a clear example of the soft skills formation in future successful professionals, because recent studies of the labour market reflect the tendency of employers to become more interested in such skills. Therefore, considering the soft skills in the process of studding foreign language for professional purposes is extremely important, which determines the relevance of this article. A systematic description of contextual analysis techniques was used to describe illustrative and theoretical material. The selection method of examples is a way to identify and organize the tasks that contribute to the successful formation of soft skills. Soft skills are skills, abilities and characteristics that allow you to be successful in professional activity: leadership skills and ability to work in a team, the ability to teach and negotiate, the ability to set and achieve goals, to manage time, presentation skills, effective communication skills, stress resistance, creativity and analytical skills. The training complex Business Partner provides the opportunity to ensure a coherent and practical business speech; an innovative approach to developing communicative skills; development of competencies and practical skills; development critical thinking, strategic thinking, ability to work collectively. Business Partner is the base for complex problem solving, critical thinking, creativity, people management, coordinating with others, emotional intelligence, judgment and decision making, service orientation, negotiation, cognitive flexibility. These skills have been identified at the World Economic Forum in Davos as essential today. Do all tasks of MyEnglishLab platform is also an effective and appropriate way to perform soft skills, which allows to increase the individualization of learning activities, to optimize the acquisition of language structures and grammatical rules, as well as to overcome the formulation of skills. 
The training complex Business Partner provides a blended learning model and incorporates the latest modern topics of economic development that allows to develop soft skills successfully. Effective formation of soft skills is the base in the professional personal activity allowing the future specialist to make a breakthrough in new branches of professional activity. The prospect of further research involves engaging students in questionnaires to identify the depth of soft skills formation based on the training complex Business Partner.

Keywords: soft skills, Business Partner, English, future skills, professional, foreign language for professional purposes.

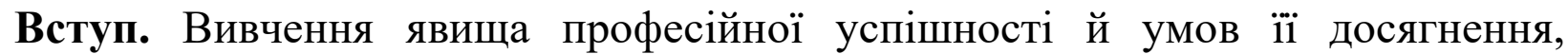
останнім часом набуло потужного розвитку у працях сучасних вітчизняних $\mathrm{i}$ зарубіжних учених. Дослідники розглядають феномен успіху в контексті єдності свідомості і діяльності, передусім як інтеріоризацію заданих у суспільстві цінностей через відповідну рефлексивну діяльність у внутрішні надбання особистості $[3,4]$.

Більшість дослідників кар'єрних процесів погоджуються 3 тим, що феномен успішності в професійній діяльності варто розглядати як комплексний, що складається 3 декількох взаємозалежних складників. Кількість цих складових в різних дослідників різна, але до їхнього складу майже всі науковці поряд з такими характеристиками, як висока майстерність, продуктивність праці, виконання професійної діяльності на рівні високих зразків і стандартів, надійність і стійкість високих результатів, відносять i навички ефективної взаємодії в професійному середовищі, особистий розвиток і самореалізацію в професії, кар'єрне зростання, високі посади в ієрархії організації, високий соціальний статус, визнання, популярність у суспільстві [5].

В. Срмолаєва наголошує, що структуру професійної реалізації утворюють три компоненти: індивідуальний (професійна самоідентифікація, або Я-концепція), інструментальний (професійні знання, вміння, навички), і соціальний (відповідність соціальному замовленню): їх збіг трактується дослідницею як професійна ідентичність, а розбіжність - як той або інший різновид професійного маргіналізму. «Реалізацію професіонала вона розглядає не тільки як самореалізацію, яка відбувається всередині суб'єкта і в інтересах суб'єкта, ступінь якої оцінює сам суб'єкт з позиції того, наскільки йому підходить ця професія, а й як реалізацію, звернену ззовні, здійснювана у формі соціальних професійних вчинків, через які вже соціум оцінює, наскільки йому підходить цей професіонал, якою мірою він відповідає його інтересам і запитам» [6].

Поняття професійний успіх І. Ткачук та Н. Сосновенко визначають як усвідомлений особистістю позитивний результат професійної діяльності, який $\epsilon$ динамічним, розгортається в часі на основі здобуття нею знань i самовдосконалення у предметно-перетворювальній діяльності у сфері 
професії, що підкріплюється іï особистісним розвитком i уможливлює соціальну самореалізацію людини [5]. I, щоб бути дійсно успішним професіоналом, потрібно володіти комплексом навичок, що є актуальними та зможуть задовольнити професійні вимоги сьогодення.

Проте, ліквідація розриву у навичках, які потребують роботодавці, та які формують вищі навчальні заклади, залишається актуальною проблемою у багатьох країнах світу. Одна 3 причин такого розриву - швидкий розвиток технологій. Ніхто не може передбачити достеменно професії майбутнього, однак спрогнозувати навички, які будуть потрібні, цілком можливо. Так, у березні 2016 року Генеральний Директорат Європейської Комісії з питань освіти та культури виніс на обговорення новий Порядок Денний з Навичок (ELI Skills Agenda), що фокусується на вищій якості навичок для всіх та кращому розумінні потреб ринку праці. У 2015 році у Північній Ірландії презентовано результати масштабного дослідження «Попит на навички» 3 метою визначення потреби у навичках у перспективі розвитку економіки країни до 2025 року. В Україні у цьому напрямку діє Центр «Розвиток КСВ», який ініціював проведення дослідження «Навички для розвитку України 2030: погляд бізнесу та освіти». Відповідно до отриманих результатів дослідження, у перспективі 2030 року найбільший попит матимуть навички (Таблиця 1):

\begin{tabular}{|l|l|}
\hline Підприсмницькі & 3.52 \\
\hline Ініціативність & 3.9 \\
\hline Лідерство & 3.47 \\
\hline Орієнтованість на клієнтів & 4.07 \\
\hline Осмислення і прийняття рішень & 3.4 \\
\hline Відповідальність & 3.6 \\
\hline Підприємливість & 3.3 \\
\hline Стратегічне мислення & 2.9 \\
\hline Інноваційні & 3,62 \\
\hline Адаптивність/гнучкість & 3,6 \\
\hline Аналітичне мислення & 3.7 \\
\hline ІТ-грамотність & 3.87 \\
\hline Креативність & 4.07 \\
\hline Критичне мислення & 2.9 \\
\hline Комунікативні & 3.26 \\
\hline Комунікабельність & 3,7 \\
\hline Емоційний інтелект & 3,4 \\
\hline Медіаграмотність & 3 \\
\hline Грамотна письмова й усна мова & 3,7 \\
\hline Ораторське мистецтво & 2,6 \\
\hline Вміння слухати & 3,2 \\
\hline Управлінські & 3 \\
\hline Управління змінами & 2,16 \\
\hline
\end{tabular}




\begin{tabular}{|l|l|}
\hline Управління конфліктами & 3,16 \\
\hline Управління людьми & 3,2 \\
\hline Управління проектами & 3,47 \\
\hline Організаційні здібності & 3,58 \\
\hline Рішення комплексних проблем & 2,8 \\
\hline Навички працювати в команді & 3,34 \\
\hline Координація з іншими & 2,5 \\
\hline Здатність швидко навчатися & 3,68 \\
\hline Вміння працювати в команді & 3,76 \\
\hline Уміння працювати під тиском/стресостійкість & 3,64 \\
\hline Вміння планувати & 3,4 \\
\hline Вміння вести переговори & 3,1 \\
\hline
\end{tabular}

Таблиия 1. Середній рівень оиінки навичок випускників ВНЗ в разі прийняття на роботу в компанію за 5-бальною шкалою (розрахований на основі абсолютних даних).

Сьогодення усі ці навички вимагає окреслювати словосполученням soft skills. У зарубіжних публікаціях є велика кількість моделей soft skills, зокрема на думку Ю. Катели, американського експерта ринку праці, складниками soft skills є: професійне спілкування; критичне мислення; робота в команді; навчання протягом життя; навички підприємництва; лідерство. Шведський дослідник А. Берглунд, зазначає, що для отримання ефективних результатів діяльності потрібні такі soft skills: розуміння професійної та етичної відповідальності за прийняття інженерних рішень; здатність до критичної рефлексії прийнятих рішень; навички управління людськими ресурсами та самоорганізації; здатність брати на себе лідерські позиції у міждисциплінарній та мультикультурній команді; розуміння важливості навчання протягом життя; - володіння прийомами аргументації і професійної комунікації; вміння працювати у багатопрофільній команді [3].

В Україні поняття soft skills є відносно новим та недослідженим, хоча останні дослідження ринку праці відображають помітну тенденцію значної зацікавленості працедавців до soft skills у роботошукачів. Більшість роботодавців вважають ї так само важливими, як і професійні знання та вміння. Тож розгляд питання розвитку soft skills у студентів під час їх навчання в університеті надзвичайно важливе, що зумовлює актуальність дослідження. Метою статті $є$ дослідження механізмів розвитку soft skills студіюючої молоді на основі опанування навчального комплексу Business Partner.

Методологія та методи дослідження. Для реалізації мети дослідження було використано комплекс Business Partner (Пірсон), що складається з навчального підручника Business Partner та онлайн платформи MEL. Метод відбору прикладів дав можливість виявити та систематизувати завдання в навчальному комплексі Business Partner як в оригіналі так і в перекладі, що сприяють 
успішному формуванню soft skills. Для систематичного опису ілюстративного та теоретичного матеріалу стосовно досліджуваної проблематики застосовуємо описовий метод з прийомами контекстуального аналізу, що передбачає спостереження, класифікацію, узагальнення та інтерпретацію.

Виклад основного матеріалу дослідження. Сдиного перекладу терміна soft skills на разі не існує, тому найчастіше при перекладі soft skills визначають як «м'які» навички (компетенції), проте зустрічаються й інші переклади, наприклад, людські або уніфіковані. Soft skills - соціологічний термін, який відноситься до емоційного інтелекту людини, свого роду перелік особистих характеристик, які так або інакше пов'язані 3 ефективною взаємодією 3 іншими людьми. Це навички, прояв яких достатньо важко виявляти, безпосередньо визначати, перевіряти, наочно демонструвати. До цієї групи належать індивідуальні, комунікативні та управлінські навички. Поняття soft skills пов'язане з тим, яким чином люди взаємодіють між собою, тобто «м'які» навички рівною мірою необхідні як для повсякденного життя, так і для роботи. За даними досліджень, професійну успішність визначають саме soft skills [2].

Soft skills об'єднують ряд психологічних характеристик, властивостей та вмінь, які можна згрупувати. Ці якості складно виміряти, а тому їх оцінка носить суб'єктивний характер. Більшість роботодавців вважають їх так само важливими, як і професійні знання та вміння. Професійні вміння та навички застарівають, a soft skills є актуальними завжди [2]. Soft skills - це навички, вміння та характеристики, які дозволяють бути успішними у професійній діяльності. До них відносять: лідерські якості та вміння працювати у команді, вміння навчати та проводити переговори, вміння ставити та досягати поставлених цілей, управління часом, цілеспрямованість, презентаційні навички, навички ефективної комунікації, стресостійкість, креативність, творчий підхід до вирішення завдань та аналітичні здібності, тощо. Сталого переліку, як і класифікації soft skills, не існує. Оскільки, зрозуміло, що для різних видів діяльності пріоритетними є різні види soft skills [1].

На Всесвітньому економічному форумі в Давосі було порушено питання про майбутне професій. Названо список тих умінь, які будуть потрібні у майбутньому:

1. Комплексне багаторівневе вирішення проблем (Complex problem solving). Це означає, що людина здатна бачити суть проблем і розбиратися 3 причиною, а не з наслідком. Найбільш затребуваними будуть ті фахівці, які будуть володіти системним, цілісним підходом до вирішення будь-яких проблем, будуть знати, на що ще звернути увагу, крім очевидного.

2. Критичне мислення (Critical thinking). Це такий спосіб мислення, при якому людина ставить під сумнів інформацію, що надходить і навіть власні переконання. Це дуже корисна навичка, тому що питання «Чи може все працює зовсім не так, як ми припускаємо?» допомагає розвитку.

3. Креативність в широкому сенсі (Creativity). Творчий початок - це здатність бачити те, чого ще немає. Коли Мікеланджело запитали, як він 
створив статую Давида, скульптор відповів: «Я побачив ангела в шматку мармуру, і мені захотілося звільнити його».

4. Уміння управляти людьми (People management). Управління людьми - це складна наука про те, як лідерам приймати головні рішення. Не просто про підлеглих, а про Людей. Як мотивувати співробітників так, щоб вони бігли підтюпцем на роботу, а не з роботи? Як не помилитися в людині, приймаючи його на роботу, і підвищувати тих, хто цього заслуговує? Як розрулювати конфлікти всередині команди? Знати відповіді на всі ціпитання - і значить володіти people management.

5. Взаємодія 3 людьми (Coordinating with others). Аскетичність може шкодити будь-якій діяльності. Якщо ви власник бізнесу, якому важко спілкуватися 3 людьми, потрібно найняти того, хто вміє налагодити контакт 3 іншими.

6. Емоційний інтелект (Emotional intelligence). Зараз під емоційним інтелектом розуміється здатність розуміти емоції, наміри і мотивацію інших людей і свої власні, а також уміння управляти своїми емоціями та емоціями інших людей.

7. Формування власної думки та прийняття рішень (Judgment and decisionmaking). Чи хочеш, чи вмієш - нікому не буде цікаво. Потрібно буде формулювати свою думку і приймати рішення. Самостійність у всьому.

8. Клієнтоорієнтованість (Service orientation). Судячи з прогнозів, сфера послуг в світі буде тільки зростати, а хороший сервіс завжди на вагу золота.

9. Уміння вести переговори (Negotiation). Уміння ясно висловлюватися, бути переконливим - трендовий навик. Найприємніше, що з практикою ним опанувати може кожен.

10. Гнучкість розуму (Cognitive flexibility). Когнітивна гнучкість - це здатність розуму швидко перемикатися 3 однієї думки на іншу, а також обмірковувати кілька речей одночасно [7].

Яскравим прикладом формування згаданих навичок у майбутніх успішних професіоналів під час опанування дисципліни «Іноземна мова за професійним спрямуванням» $є$ навчальний комплекс Business Partner. Це багаторівневий курс для вивчення англійської мови, необхідної для успішного ділового спілкування. Business Partner - це модель змішаного навчання сучасного освітнього середовища, що має три основних компоненти і які функціонують у постійному взаємозв'язку: 1. Очне навчання (face-to-face) традиційний формат аудиторних занять викладач - студент за підручником Business Partner. 2. Самостійне навчання (self-study learning) - це самостійна робота студентів, що передбачена навчальним комплексом. 3. Онлайн навчання (online collaborative learning) - робота студентів і викладачів в режимі онлайн на інтерактивній платформі MyEnglishLab.

Комплекс BUSINESS PARTNER включає найновішу i найбільш потрібну сучасному розвитку економіки тематику, відповідно до якої студенти опановують дисципліну ІМПС, наприклад (Рис.1, Рис. 2): 


\begin{tabular}{|l|l|}
\hline$\square$ & $\vee$ Unit 1: Organisation
\end{tabular}

Рисунок 1. Тематика Business Partner B1+.

\begin{tabular}{|c|c|c|c|}
\hline$\square$ & $\checkmark$ & Unit 1 Career choices & ( \\
\hline$\square$ & $\checkmark$ & Unit 2 Business sectors & ( \\
\hline$\square$ & $\vee$ & Unit 3 Projects & () \\
\hline$\square$ & $\vee$ & Unit 4 Global markets & ( \\
\hline$\square$ & $\checkmark$ & Unit 5 Design and innovation & O \\
\hline$\square$ & $\vee$ & Unit 6 Safety and security & () \\
\hline$\square$ & $\checkmark$ & Unit 7 Customer service & O \\
\hline$\checkmark$ & $\checkmark$ & Unit 8 Communication & (2) \\
\hline
\end{tabular}

Рисунок 2. Тематика Business Partner B1.

Усі, завдання, що виконують студенти за різними темами комплексу Business Partner передбачають успішне формування усіx soft skills. Наприклад, навички уміння управляти людьми (People management) (Рис. 3): 


\section{Lesson 8.4 Business skills: Leading meetings}

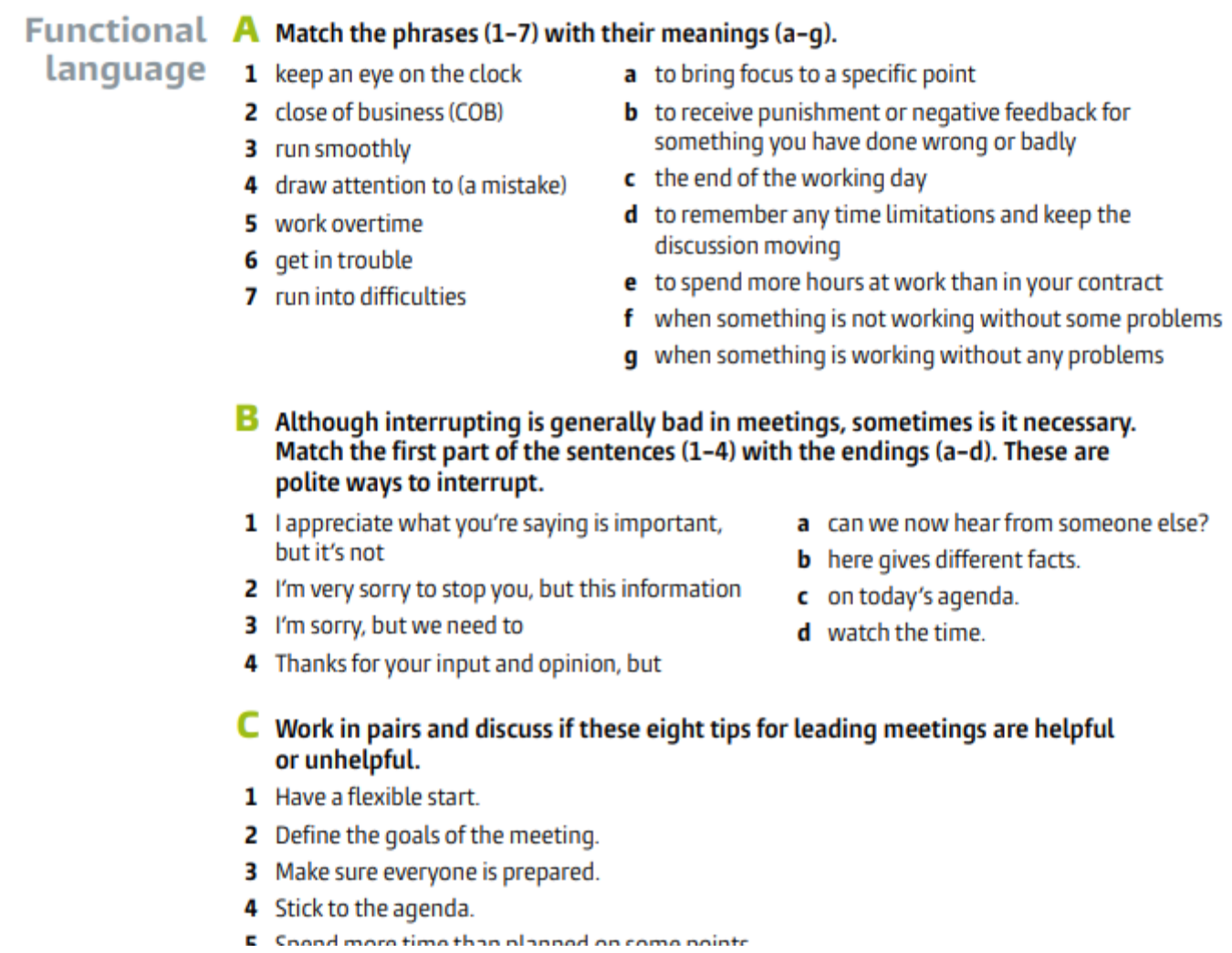

Рисунок 3. Завдання з інтерективної онлайн платформи MEL.

Навички креативності формуються у процесі творчих завдань, наприклад, Look at the picture. Write a description of the picture in English. Write as much as you can. Use complete sentences.

Формування навичок гнучкості розуму (Cognitive flexibility) відбувається під час виконання усіх завдань як у співпраці, так і в процесі самостійної роботи, наприклад, Rewrite the passage using your own words. After writing, click 'Submit'. Then, click 'Show model answer' to compare your writing to the model answer and see the original text.

Завдання, що спрямовані на формування навичок власної думки та прийняття рішень (Judgment and decisionmaking): Decide if the statements are true $(T)$ or false $(F)$; Which text summarises the main information in the article?; Read the article again and answer the questions; Before you read, choose the correct $d e \neg$ nition ( $a$ or b) for the words/phrases in bold in these sentences. Then read the article to check your answers. 


\section{Уміння вести переговори (Negotiation) (Рис. 4):}

Functional A complete the dialogue using the words in the box.

language

include confirm suggest prefer agree need

Jo: Thanks for coming today. As you can see from the agenda, the main objective is to ${ }^{1}$ __ a pricing level for next year. I know you've prepared some ideas, so would you like to start?

Sam: My proposal is quite simple. I would ${ }^{2}$ that we reduce prices by 5 percent across all products and services, which should give you a significant saving. How does that sound?

Jo: When you specify all products, does that also ${ }^{3}$ the technical support that we buy from you?

Sam: No, technical support is a separate area. It requires more expertise, which is more expensive for us to supply.

Jo: $\quad \mathrm{OK}, \mathrm{I}$ would 4 __ to include all services, including support.

Sam: Well, as I say, this form of consultancy is very expensive.

Jo: $\quad 0 K$, can we agree to reduce technical support by 2 percent? I some movement on this.

Sam: $0 K, 2$ percent sounds fair.

Jo: Good. Then we agree 5 percent on products and 2 percent on support. I will 6 this in an email and send out new contracts to sign.

Sam: Very good.

Jo: Thanks, Sam. I appreciate your flexibility here.

$B$ Read the dialogue again and find the phrases which correspond to each of the following steps $(\mathrm{a}-\mathrm{g})$ in the negotiating process.

a Welcome

b Invite the other party to present

c Request feedback on own ideas

Рисунок 4. Завдання з інтерективної онлайн платформи MEL.

Завдання, що спрямовані на формування навичок взаємодії з людьми (Coordinating with others) (Рис. 5):

Lesson 1.4 Business skills: Small talk in first meetings

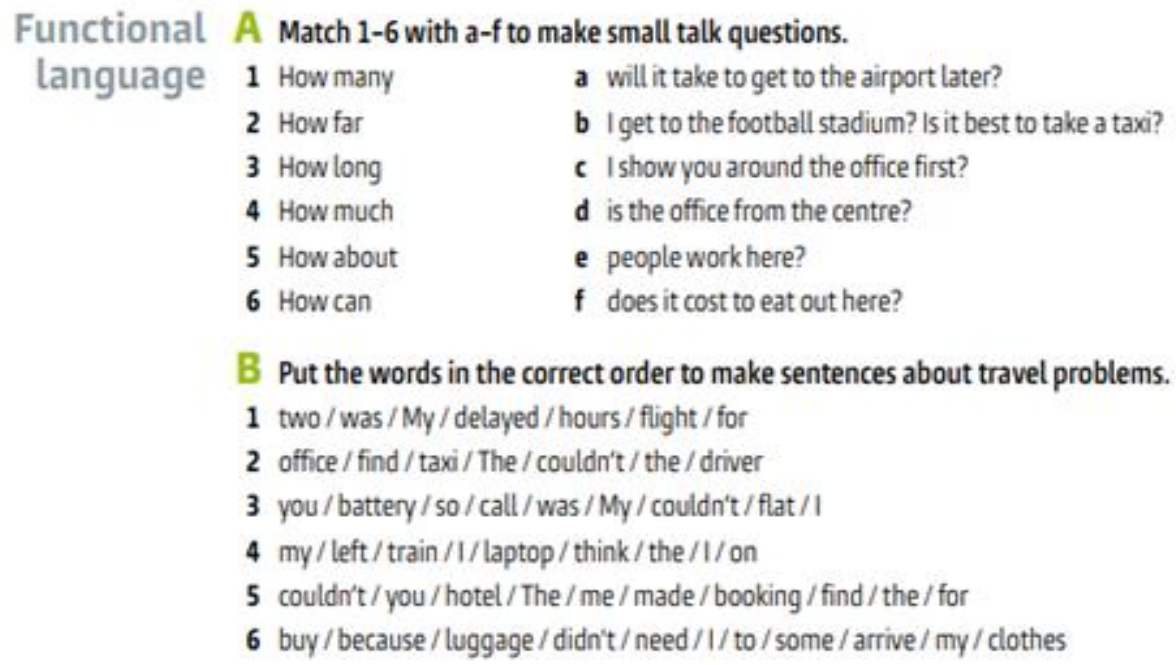

Рисунок 5. Завдання з інтерективної онлайн платформи MEL. 
Завдання, що спрямовані на формування навичок клієнтоорієнтованості (Service orientation) (Рис. 6):



Рисунок 6. Завдання з інтерективної онлайн платформи MEL.

Усі навички є необхідними для успішного фахівця. Формування soft skills відбувається безперервно та ефективно під час виконання усіх завдань навчального комплексу Business Partner.

Висновки 3 дослідження. Пріоритетом вищої освіти сьогодення $\epsilon$ забезпечення ефективної та якісної підготовки майбутніх фахівців, яку в сучасному світі неможливо уявити без використання сучасних підходів до формування soft skills. Використання навчального комплексу Business Partner на заняттях 3 опанування дисципліни «Іноземна мова за професійним спрямуванням» дає можливість забезпечення сучасного та практичного ділового мовлення (особливо статтям Financial Times); інноваційного підходу для розвитку комунікативних навиків за допомогою відео; розвитку компетенцій та особистісних навичок, необхідних для роботи в бізнес середовищі; розвитку критичного та стратегічне мислення, вміння праюцювати колективно; виконувати завдання на платформі MyEnglishLab, що $є$ ефективним та доцільним засобом змішаного навчання англійської мови, 
спрямована на розвиток комунікативних здібностей, що дозволяє підвищити індивідуалізацію навчальної діяльності, оптимізувати засвоєння мовних структур та граматичних правил, а також подолати монотонність при формуванні мовленнєвої та комунікативної компетенції при навчанні англійській мові.

Успішне формування soft skills (вміння переконувати, знаходити підхід до людей, лідирувати, міжособистісне спілкування, ведення переговорних процесів, робота в команді, особистісний розвиток, управління часом, ерудованість, креативність та ін.) дозволяє досягати вершин у всіх сферах професійної діяльності людини, що дасть майбутньому спеціалісту реалізувати прорив у нові галузі фахової діяльності.

Перспектива подальших досліджень передбачає залучення студентів до анкетування 3 метою виявлення глибини формування soft skills на основі навчального комплексу Business Partner.

\section{ЛІТЕРАТУРА}

1. Длугунович H. A. Soft skills як необхідна складова підготовки ITфахівців. Вісник Хмельницького національного університету. Технічні науки. Хмельницький, 2014. № 6. С. 239-242.

2. Коваль К. О. Розвиток «soft skills» у студентів - один 3 важливих чинників працевлаштування. Вісник Вінницького політехнічного інституту. Вінниця, 2015. № 2. С. 162-167.

3. Лавриш Ю. Навички соціальної взаємодії як необхідна складова підготовки інженерів у сучасному університеті. Гуманітарний вісник Державного вищого навчального закладу «Переяслав Хмельнищький державний педагогічний університет імені Григорія Сковороди». Психологія. Переяслав Хмельницький, 2015. Вип. 37. С. 104-111 .

4. Ткачук I. I. Формування у старшокласників спрямованості на майбутній професійний успіх : дис... канд. пед. наук: 13.00.07/ Інститут проблем виховання НАПН України. Київ, 2016. 298 с.

5. Ткачук I., Сосновенко Н. Розвиток «soft skills» у студентів коледжів. URL: $\quad$ https://lib.iitta.gov.ua/717748/1/Tkachuk_Sosnovenko_soft\%20 skills 2019 16-18.pdf (дата звернення: 30.04.2020).

6. Ермолаева Е. П. Профессиональная идентичность и маргинализм: концепция и реальность. Психологический журнал. Москва, 2001. № 4. С. 51-59.

7. 10 професійних навичок, якими має оволодіти людина до 2020 року. URL: http://tvoemisto.tv/news/10_profesiynyh_navychok_yakym_maie ovolodity_lyudyna_do_2020_roku_76398.html4 (дата звернення: 19.01.2020).

8. Lansford L. Business Partner B1 Teacher's Resource Book with MyEnglishLab. Longman (Pearson Education), 2018. 208 p.

9. Wade B. \& Karyda M. Business Partner B1+. Teacher's Resource Book with MyEnglishLab. Longman (Pearson Education), 2018. 208 p. 